Meta

Journal des traducteurs

Translators' Journal

\title{
Not-for-Profit Crowdsource-based Translation Technology
}

\section{Tabea De Wille, Chris Exton, Reinhard Schäler et Asanka Wasala}

Volume 60, numéro 2, août 2015

$60^{\mathrm{e}}$ anniversaire. Les horizons de la traduction : retour vers le futur

$60^{\text {th }}$ Anniversary. Translation's Horizons: Back to the Future

$60 \mathrm{mo}$ aniversario. Los horizontes de la traducción: regreso al futuro

URI : https://id.erudit.org/iderudit/1032877ar

DOI : https://doi.org/10.7202/1032877ar

Aller au sommaire du numéro

\section{Éditeur(s)}

Les Presses de l’Université de Montréal

ISSN

0026-0452 (imprimé)

1492-1421 (numérique)

Découvrir la revue

Citer ce document

De Wille, T., Exton, C., Schäler, R. \& Wasala, A. (2015). Not-for-Profit

Crowdsource-based Translation Technology. Meta, 60(2), 326-326.

https://doi.org/10.7202/1032877ar 


\title{
Not-for-Profit Crowdsource-based Translation Technology
}

\author{
Tabea De Wille, Chris Exton, Reinhard Schäler \\ and ASANKA WASALA \\ University of Limerick, Limerick, Ireland \\ chris.exton@ul.ie; tabea.dewille@ul.ie; asanka.wasala@ul.ie; reinhard.schaler@ul.ie
}

Traditional forms of language translation based on a professional pool of translators cannot cope with the future needs and demands of humanity. This is due to many factors, not least of which is the ever-growing user generated content and accessibility of the World Wide Web. Crowdsourcing based on a non-profit translation community has been described as one approach to address the shortcomings of current mainstream translation efforts, allowing the decisions about what should be translated to be shifted from large corporations to the individual or the crowd. To empower language communities, at the Localisation Research Centre (LRC) we have developed a web-based translation platform known as Service-Oriented Localisation Architecture Solution (SOLAS) for volunteer communities. SOLAS was conceived at The Rosetta Foundation Design Fest in San Francisco, February 5-6, 2011. The SOLAS consists of two components: SOLAS Match (matching projects and volunteers) and SOLAS Productivity (a suite of translation productivity tools and language resources). SOLAS is an integral part of a wider generic common online space, owned by everybody, driven by nonmarket considerations, and managed and protected for the benefit of everybody known as Translation Commons (Trommons).

It is our view that this new model of crowdsourcing may provide equal access to information and knowledge regardless of language. In this paper we describe the current system's design from the user perspective, particularly focusing on how we have used commonly used concepts in crowdsourcing platforms such as badges, tags and rating systems to deal with more high-level concerns such as motivation, quality, domain classification and related translator knowledge and reputation. In addition, we provide some up-to-date data relating to the current system's growth and utilisation.

Ms. Tabea De Wille holds an MA (Magister Artium) in German and English Linguistics from the University of Erlangen-Nürnberg, Germany and an MSc Multilingual Computing and Localisation from the University of Limerick, Ireland. She is currently a PhD student at the Localisation Research Centre, University of Limerick, Ireland, where she examines quality in social localisation. Her main research interest lies in how the community on Trommons defines and negotiates translation quality, and how translation quality is perceived in a volunteer vs. commercial setting. 